\title{
Implication of the Plant Species Belonging to the Brassicaceae Family in the Metabolization of Heavy Metal Pollutants in Urban Settings
}

\author{
Magdalena Nikolić*, Vladimir Tomašević \\ Environmental Science, School of Engineering Management, Serbia
}

Received: 2 April 2020

Accepted: 23 May 2020

\begin{abstract}
Environmental hazards have motivated the development of a novel perspective of urban environmental quality as a planning strategy prerequisite for the integration of greenery resources in urban infrastructures. The accurate genotype stress response presents a condition for urban adaptation of plants. The goal of this review paper is to present phytoremediation at molecular levels via genes related to transport, accumulation and sequestration/detoxification of heavy metals from the environment. The overexpression/alteration of the native plant-specific gene(s) and transgenic plants whose metal-uptake proteins and metal-efflux proteins enable efficient metal uptake and transport, give rise to transgenic approaches. In a line with this, overexpression/alteration of a gene(s) encoding for phytochelatins and glutathione increase the sequestration of toxic HMs in the vacuoles. Since tolerance to high levels of metals by hyperaccumulators is under genetic control, many studies used genetic approaches to define the genetic determinants of these hyperaccumulators. Many plant species, particularly members of the Brassicaceae family are known heavy metal hyperaccumulators. This paper examines molecular aspects of hyperaccumulator plant species from genera Brassica, Noccea, Alyssum and Arabidopsis in phytoremediation of heavy metal polluted environments, and provides an overview of potential transferable genes that could improve metal tolerance and/or accumulation, as the major targets for phytoremediation. Therefore, plant species identified to have the potential to grow and remediate the heavy metal polluted urban environments require greater attention.
\end{abstract}

Keywords: heavy metals, environmental pollution, hyperaccumulator genes, Brassicaceae for urban settings

*e-mail: magdalenanikolic3@gmail.com 


\section{Introduction}

One of the major global and recurrent environmental issues is the pollution of soil and water with heavy metals (HMs), with negative effects on ecosystems and public health, and subsequent economic losses. Considering that around $75 \%$ of periodic table elements are metals, a growth in their use increases the amount of metallic substances in the environment [23]. Minerals weathering, erosion, and volcanic activity are the most important natural sources of these metals in the environment. There are many more anthropogenic sources of heavy metals: industrial discharges, industrial mining, smelting, electroplating, agricultural use of organic and chemical fertilizers, biosolids and pesticides; emissions from incinerators of municipal waste, car exhausts; atmospheric deposition; sludge dumping, etc. Elemental pollutants such as arsenic (As), copper $(\mathrm{Cu})$, cadmium $(\mathrm{Cd})$, mercury $(\mathrm{Hg})$, nickel $(\mathrm{Ni})$, zinc $(\mathrm{Zn})$, and lead $(\mathrm{Pb})$ are toxic elements that cannot be converted by any biochemical reaction, and therefore persist in the ecosystem [39]. The ubiquitously present pollutants found at waste sites are metals and other inorganic contaminants. However, their remediation is one of the most technically challenging, because metals cannot be degraded, unlike organic contaminants [49]. Certain plant species have the genetic potential to remove, degrade, metabolize, or immobilize a wide range of contaminants from soil and water. The ability to tolerate high concentration of toxic heavy metals is related to specific genes related to phytochelatins and glutathione pathway for vacuolar heavy metal sequestration, and antioxidant defense system [2]. These plants belong to more than 50 families, $25 \%$ of which are from family Brassicaceae [22].

\section{The Implication of Brassicaceae in the Remediation of Urban Environments}

Urban soils are known recipients of large amounts of heavy metals from a variety of anthropogenic sources, including industrial wastes, vehicle emissions, coal-burning waste, and other activities. Heavy metals in public areas (such as gardens and parks) are particularly hazardous because of human exposure to significant pollution levels [57]. Plants belonging to the Brassicaceae family are suitable for phytoremediation because of considerable growth rate and high biomass [51]. For instance, Arabidopsis halleri and Arabidopsis arenosa are more tolerant of heavy metals compared to Arabidopsis thaliana, therefore this plant gives insight in processes that take place during heavy metal toxicity [67]. Species whose roots contain more than $100 \mathrm{mg}$ $\mathrm{Cd} \mathrm{x} \mathrm{kg}^{-1}, 1,000 \mathrm{mg} \mathrm{Ni}$ and $\mathrm{Cu} \mathrm{x} \mathrm{kg}^{-1}$, or more than $10,000 \mathrm{mg} \mathrm{Zn}$ and $\mathrm{Mn} \times \mathrm{kg}^{-1}$ (dry weight) when grown in metal-rich soils are hyperaccumulator plant species [1]. Furthermore, genetic modification/manipulation can greatly increase this potential. These transgenic strategies involve genes encoding for specific metal uptake and transport proteins. Invoking enhancement of adaptive capacity in the adaptability of transgenic varieties, phytoremediation will be greatly improved [2]. Best-known examples of hyperaccumulator species in the Brassicaceae family are Noccea caerulescens subsp. virens (Jord.) Kerguélen I, Alyssum (Alyssum murale Waldst. \& Kit.; Alyssum lesbiacum (Candargy) Rech.f. and Arabidopsis (Arabidopsis halleri (L.) (O'Kane \& Al-Shehbaz) [syn. Cardaminopsis halleri (L.) Hayek], Arabidopsis thaliana (L.) Heynh). [21] Coronopus didymus (L.) Sm. [65, 66] Barbarea arcuata (Opiz ex J.Presl \& C.Presl) Rchb rorippa palustris (L.) besser, Brassica campestris (L.) [19], Brassica rapa (L.) [87].

\section{Specific Genes in Similar Species Involved in Heavy Metal Tolerance and Accumulation}

\section{Uptake by Metal Transporters in the Plasma Membranes}

Plants possess two classes of heavy metal transporter proteins categorized into metal-uptake proteins and metal-efflux proteins. Metal-uptake proteins can transport essential heavy metals into the cytoplasm. Metal-efflux proteins catalyze the efflux of toxic heavy metals from the cytoplasm, or move these metals into the vacuole, helping plant detoxification [36]. These proteins include cation diffusion facilitator (CDF) family, heavy metal CPx-ATPases, Nramp (natural resistance-associated macrophage protein) family and ZIP (Zinc-regulated transporter ironregulated transporter Proteins) family [29]. Enhanced metal uptake from the roots and translocation to the shoots in hyperaccumulators is a tightly controlled process mediated by membrane transport proteins. $N$. caerulescens contains at least three different expressed genes: ZTP1 that is highly similar to the Arabidopsis ZAT-Zn gene, and ZNT1 and ZNT2 that resemble the Arabidopsis AtZIP4 gene, especially ZNT1 with $90 \%$ cDNA and $87 \%$ amino acid overlap [44]. In Zrt this sequence is HDHDHD and in $\mathrm{Irt}_{1}$, this motif is GHGHGH. These histidine-rich motifs are part of the putative cytoplasmic domain, which may define a putative metal binding site for the transporter [52]. According to Salome (2019), limeinduced chlorosis/ iron-deficient plants showed limited expression of $\mathrm{Fe}^{+2}$ IRT1 transporter to roots. Also, the potential for cobalt and cadmium uptake was observed [60]. Compared to the wild type, overexpression of NcZNT1 in transgenic Arabidopsis plants indicated increased $\mathrm{Zn}$ and $\mathrm{Cd}$ tolerance and accumulation, when compared to non-transformed wild-type plants. Also, Zn deficiency activation of NcZNT1and AtZIP4 promoters in A.thaliana reviled the usual cis-regulatory sequences in both promoters associated with gene regulation. Furthermore, both AtZIP4 and NcZNT1 promoters were involved in the $\mathrm{Zn}$ deficiency response. 
However, under low zinc regimes, the activity of the $N$. caerulescens NcZNT1 promoter expression was higher [45]. As reported by Teng et al. (2019) N. caerulescens $\mathrm{Ni}$ exposure activated NcIRT1 expression to higher Fe accumulation, at the same time, Fe deficiency increased $\mathrm{Ni}$ accumulation. Increased $\mathrm{Zn}$ uptake is driven by overexpression of members of the ZIP family of transporters. Additionally, this research showed that $\mathrm{Ni}$ exposure triggers the $\mathrm{Zn}$ transporter gene NcZIP10, and the Fe transporter gene NcIRT1, indicating their role in Ni uptake [73]. Also, A. thaliana Ni exposure led to increased $\mathrm{Fe}$ accumulation in plants by the $\mathrm{Fe}$ (II) transporter gene IRT1 activation [73]. Some heavy metal transporter cDNAs are very likely involved in both root metal uptake and metal partitioning between the root and shoot tissues in A. halleri (e.g., ZIP6), and $N$. caerulescens (e.g., ZIP4). Other candidate genes, HMA2, and HMA4 encode for a plasma membrane protein of P-type ATPase family (HMAs) involved in hyperaccumulation and hypertolerance to $\mathrm{Zn}$ and $\mathrm{Cd}$ in A. halleri [8, 71]. The AtHMA4/ NcHMA4 highly expressed in roots and shoots of both $A$. halleri and $N$. caerulescens evidence the role of HMA4 in xylem metal loading in roots, in metal exclusion from metalsensitive tissues (root tip, cambium), and metal distribution within leaves [30]. Brassica rapa (L) is another candidate plant with high $\mathrm{Cd}$ accumulation potential. The heavy metal ATPase gene BrHMA3 was identified as a gene that encodes a tonoplast-localized $\mathrm{Cd}$ transporter, with the role in the $\mathrm{Cd}$ root to shoot translocation $[55,87,88]$.

Transport in plants is also mediated by the NRAMP (natural resistance-associated macrophage protein) family transporters. In Arabidopsis six of seven NRAMP proteins are divided into two groups. AtNRAMP1 and AtNRAMP6 belong to the first group, and $A t$ NRAMP2 through 5 comprise the second group [61]. While $A t$ NRAMP1 acts as a physiological $\mathrm{Mg}$ transporter, the AtNRAMP3, and AtNRAMP4 mediate the remobilization of $\mathrm{Fe}$ from the vacuolar store [60]. Besides, AtNRAMP3 functions as Fe, Mn, Cd, and $\mathrm{Zn}$ transporter between the vacuole and the cytosol, and its function is linked with Fe. While under Fe sufficient conditions, overexpression of $\operatorname{AtNRAMP} 3$ does not change metal content; under Fe starving condition overexpression of $A t \mathrm{NRAMP} 3$ reduces $\mathrm{Zn}$ and $\mathrm{Mg}$ in the cell [29]. AtNRAMP4 is responsible for $\mathrm{Fe}, \mathrm{Mn} \mathrm{Cd}$ and $\mathrm{Zn}$ transport, while AtNRAMP6 transports $\mathrm{Cd}$ and regulates the distribution of $\mathrm{Fe}$ and $\mathrm{Mn}$ within the cell [13]. Many members of ATPase and NRAMPs were identified in both $A$. halleri and A. thaliana. Similarly, $N$. caerulescens $N c$ NRAMP3 and NcNRAMP4 can transport various metal cations, including $\mathrm{Fe}, \mathrm{Mn}, \mathrm{Cd}$, $\mathrm{Ni}$, and $\mathrm{Zn}[61]$.

While the ZIP, P-type ATPases (HMAs), and NRAMPs influx protein families are responsible for uptake of metals such as $\mathrm{Zn}$ and $\mathrm{Cd}$ from the soil, transport into the cells and distribution throughout the plant, the efflux CDF proteins are involved in metal vacuolar sequestration [32]. Within the Arabidopsis genome, 12 nucleotide sequences encode members of the CDF transporter family [84]. The ZAT/ZTP1/MTP1 gene belonging to the CDF family of cation transporters identified in $N$. caerulescens bears sequence homology to the A. thaliana transporter AtMTP1 (At2g46800) [41]. A. halleri AtMTP1 gene highly expressed in leaves and roots [19] encodes a vacuolar membrane $\mathrm{Zn}$ transporter, responsible for metal sequestration in leaf vacuoles [42]. However, differential expression of MTP1 genes variations in A. halleri, and different $\mathrm{Zn}$ tolerance levels when expressed in yeast, indicate different evolutionary fates for different copies of MTP1 genes [20,63] Also, it was found that up-regulation of Fe-deficiency response genes, such as AtMTP3, contributes to metal homeostasis in non-accumulator $A$. thaliana [5]. ZTP1 shares high sequence homology with NgMTP isolated from the Ni hyperaccumulator, Noccea goesingense. Like NcZTP1 and AtMTP1, NgMTP1 is located in vacuolar membrane [46]. In nonaccumulator A. thaliana, AtMTP1, PtdMTP1, AtMTP3, and NgMTP1 genes were involved in increased $\mathrm{Zn}$ accumulation [31]. The source is not in the list of reference. Transgenic Arabidopsis thaliana (SULTR3 quintuple mutant) shows increased sulfur uptake via sulfate transporter SULTR3 subfamily encoded by the Sultr gene. Placed into chloroplast membrane, SULTR 3 transporter increased sulfate influx into the chloroplast for more than than $50 \%[6,11]$. Also, Arabidopsis basic helixloop-helix transcription factors FIT, AtbHLH38, and AtbHLH39 are involved in plant Cd-Fe interactions [81]. Furthermore, there is a link between over co-expression of FIT with AtbHLH38 or AtbHLH39 and triggering HMA3, MTP3, IREG2, IRT2, NAS1, and NAS2 which has a role in vacuole HM sequestration as well in the synthesis of NA [81].

Tolerance to heavy metals, especially $\mathrm{Mg}$ and $\mathrm{Ni}$, plays a crucial role in plant adaptation to serpentine soils. The well-known role of $\mathrm{Ca}$ is not only in growth and metabolic regulation but also $\mathrm{Ca}$ regulate the function of membrane protein transport systems and gene expression. Detoxification system is also based on a $\mathrm{Ca}$ role in glutathione and phytochelatin synthesis, thereby prevention metal ions entering the cell [26]. Therefore, genes involved in Arabidopsis and Alyssum $\mathrm{Ca}: \mathrm{Mg}$ and $\mathrm{Ca}$ : $\mathrm{Ni}$ homeostasis are key factors associated with the toxic concentration of essential metals [72, 86]. A vacuolar membrane transporter, cation/proton antiporters, and calcium exchanger 1 CAX1 is $\mathrm{Ca}^{2+} / \mathrm{H}^{+}$antiporter that reduces cytosolic calcium and enhances $\mathrm{Mg}$ and Ni tolerance. According to Ghasemi et al. (2018), the enhanced concentration of calcium in the cytosol was related to increasing $\mathrm{Ni}$ and $\mathrm{Mg}$ tolerance. Additionally, A. thaliana mutation of CAX 1 causes increase Cd sensitivity and decreased $\mathrm{Ni}$ tolerance. Taking into consideration that in serpentine soil $\mathrm{Ca}$ is very low compared to $\mathrm{Mg}$ and $\mathrm{Ni}$, without a minimum cytosolic $\mathrm{Ca}$ concentration, $\mathrm{Ni}$ tolerance trough Ni detoxifying mechanisms would be successful 
in Alyssum inflatum [24, 25]. Furthermore, the Alyssum inflatum and Alyssum lanceolatum genetic structure indicate HM tolerance in Alyssum, thus, identifying candidate genes such as CAX1 was essential for understanding plant adaptation to serpentine soil [53].

\section{Chelation and Sequestration}

Chelation and sequestration of heavy metals by particular ligands happen both at cellular and subcellular levels, in leaf epidermal cells and/or in cell walls and vacuoles from hyperaccumulator plants [2, 90]. By binding the PCs in complexes with heavy metals and sequestering the complexes inside their cells, plants avoid metal toxicity $[2,83]$. Plants also produce a range of ligands for $\mathrm{Cd}, \mathrm{Cu}, \mathrm{Ni}$, and $\mathrm{Zn}$. The ligands include carboxylic acids, such as citric, malic, etc., and amino acids, such as histidine (His) [90].

\section{Nitrogen Donor Ligands}

Nicotianamine (NA) is a nonproteinogenic amino acid that forms strong complexes with most transition metal ions, and its role seems to be metal hyperaccumulation, both in A. halleri and in N.caerulescens [5]. Enzyme NA synthase (NAS) is involved in chelation of many transition metal ions [9]. Consider to be one of the major ligands, NA is involved in hyperaccumulation of $\mathrm{Zn}, \mathrm{Cd}$, and $\mathrm{Ni}$ [15] as well as iron $(\mathrm{Fe})$, copper $(\mathrm{Cu})$, and manganese $(\mathrm{Mn})[33,64]$.

Moreover, the expression of NAS1 and NAS2 (nicotianamine synthases) genes is Cd up-regulated, because of high concentrations of metal-chelator nicotianamine (NA), indicating NA involvement in Cd-tolerance [5]. Higuchi et al. (1999) purified NAS protein and isolated, cloned, and characterized NAS1, NAS2, NAS3, NAS4, NAS5-1, NAS5-2, and NAS6 genes encoding $H v \mathrm{NAS}$ and HvNAS-like proteins from Fe-deficient barley (Hordeum vulgare L. cv Ehimehadaka no. 1) roots [34]. To identify the gene encoding NAS in Arabidopsis thaliana, Suzuki et al. (1999) used the nucleotide sequence of the NAS gene from barley (HvNAS). Searching A. thaliana databases, they found several ESTs and three genomic sequences highly homologous to HvNAS. The authors isolated the NAS orthologues in A. thaliana AtNAS (AtNAS1, $A t \mathrm{NAS} 2$, and $A \mathrm{tNAS} 3$ ). The expression of $A t \mathrm{NASl}$ was detected in both shoots and roots of $A$. thaliana, AtNAS3 expression was only detected in the shoots, while AtNAS2 expression was not detected in any organs [70]. Increase NA synthesis in A.thaliana roots was $\mathrm{Zn}$, and $\mathrm{Cd}$ hyperaccumulation indicator [16]. However, decreased synthesis of NA has the opposite effect on $\mathrm{Ni}$ accumulation. Investigating, $\mathrm{Zn}$ tolerance of A.halleri wild type and AhNAS2-RNAi interference plants, Cornu et al. (2015) showed a strong relation between increase NA synthesis in both plants exposed to elevated $\mathrm{Zn}$ concentration. Also, it was shown that A.halleri NAS genes are involved in the adaptation of AhNAS2-RNAi transgenic plants. Zinc-induced Facilitator 1 (ZIF1) is an important $\mathrm{Zn}$ related protein placed in the vacuolar membrane of A.thaliana. However, this protein family is highly tight to NA when it comes to $\mathrm{Zn}$ root to shoot translocation. Thus, ZIF is not able to transport Zn-NA complexes or $\mathrm{Zn}$ alone, but with coexpression of ZIF1 and a NAS gene [13]. Furthermore, there is one more membranelocalized protein family, yellow strip-like (YSL) gene family related to $\mathrm{Fe}(\mathrm{II})-\mathrm{NA}$ yeast transporter [17]. Brassica juncea BjYSL7 encodes for this group of transporters, that has been involved not only in Fe but also in $\mathrm{Cd}$ and $\mathrm{Ni}$ root to shoot translocation. Moreover, with a $90 \%$ sequence identity with $N$. caerulescens NCYSL7 and A.thaliana AtYSL7 [78]. YSL members in Arabidopsis, AtYSL1 and AtYSL3 predominantly mediate $\mathrm{Fe}(\mathrm{II})-\mathrm{NA}$ and $\mathrm{Fe}(\mathrm{III})-$ citrate, $A t \mathrm{YSL} 2$ besides transporting $\mathrm{Fe}(\mathrm{II})-\mathrm{NA}$ transport $\mathrm{Cu}-\mathrm{NA}$ in yeast AtYSL4 and AtYSL6 are reported to localize in the vacuole membrane and chloroplast envelope in response to the detoxification of excessive metals in plant cells although there is no transport capacity for $\mathrm{Fe}(\mathrm{II})-\mathrm{NA}$ in the yeast $[10,15,18]$. Additionaly, Chen et al. (2018) have cloned the YSL1 gene from M. sacchariflorus $M s Y S L 1$ is a transporter involved in the creation of metal-NA complexes in vivo. The overexpression of MsYSL1 in transgenic Arabidopsis increased $\mathrm{Cd}$ detoxification and translocation [10].

Sedum alfredii Hance SaNAS1 encoded protein responsible for enhanced $\mathrm{Cd}$ and $\mathrm{Zn}$ roots and shoots uptake. Transgenic Arabidopsis plants expressing SaNAS1 showed the same pattern associated with increased $\mathrm{Cd}$ and $\mathrm{Zn}$ accumulation, tolerance and nicotianamine production in plants $[7,12]$. Also, microarray analysis in $N$. caerulescens showed that all four NAS genes were highly expressed in $N$. caerulescens compared to non-hyperaccumulator A. thaliana when exposed to high levels of $\mathrm{Zn}, \mathrm{Cd}$, and/or Ni [75].

Amino Acids (AA) is also known as a group of nitrogen donor ligands as Changed pathways of nitrogen utilization of tested plants were noted. The glutamic acid and glutamate contents in plant biomass were decreased under $\mathrm{Cd}$ content more than $60 \mathrm{mg} / \mathrm{kg}$ soil [89]. According to Zemanova et al. (2013), under $\mathrm{Cd}$ stress for $N$. caerulescens glutamate were main for nitrogen transport, while for A. halleriare asparagine were noted. Also, under $\mathrm{Cd}$ stress, the content of aspartic acid and proline was determined only in $N$. caerulescens, while A.halleriare didn't show any changes. At the molecular level, heavy metal tolerance of plants is under the regulatory genes, that encode various transcription factors (TFs) and/or functional genes encoding metabolic compounds such as amines, etc. [67]. In $A$. thaliana exposed to $\mathrm{Cd}$, various $\mathrm{TFs}$ families, AP2/ERF superfamily and ERF1 and ERF5, as well as the dehydration-responsive element-binding protein (DREB) transcription factor were induced [4]. However, Brassica oleracea AP2/ERF-like genes 
haven't had an expression profile exposed to abiotic stress (74). Furthermore, 5-aminolevulinic acid (ALA), is a well-known growth regulator, that is proved to be involved in $\mathrm{Cd}$ tolerance in Brassica napus $\mathrm{L}$. Moreover, ALA-induced $\mathrm{Cd}^{2+}$ tolerance in B. napus is related to gene expression of antioxidant enzymes superoxide dismutase (SOD), catalase (CAT), and peroxidase (POD) as well as glutathione, carotenoids, and ascorbate [3].

\section{Sulfur Donor Ligands}

Phytochelatins (PCs) and metallothioneins (MTs) belong to different classes of cysteine-rich, heavy metal-binding proteins [8, 14]. PCs are enzymatically synthesized peptides, from the tripeptide glutathione ( $\gamma$-Glu-Cys) -Gly) [62, 68]. PCs are not genetically encoded but are non-ribosomal peptides [7]. Also, PC peptides are not primary translation products of mRNAs but are synthesized enzymatically [63]. The synthesis of PC is followed by a decrease in cellular levels of glutathione (GSH) [50]. As products of an enzymatic reaction involving the enzyme PC synthase, PCs are positively correlated with metal accumulation in plant tissues [50], i.e., plants naturally produce phytochelatins when exposed to $\mathrm{Cd}, \mathrm{Pb}, \mathrm{Zn}, \mathrm{Ag}$, $\mathrm{Hg}$, As and $\mathrm{Cu}$. Because of the structural similarity between PCs and GSH, GSH is thought to be the substrate for PCs biosynthesis [8, 14]. As a precursor of PCs, GSH- dependent pathway takes place in $\mathrm{Cd}$ sequestration [5, 9]. Also, GSH has a crucial role as a cellular antioxidant, as a reactive oxygen species (ROS) signaling molecule, and as a metal chelator [42]. In comparison to nonaccumulators, high concentrations of cysteine O-acetylserine and GSH were found in Ni-hyperaccumulating Noccaea species and hyperaccumulators $N$. caerulescens and $N$. goesingense. Increased serine acetyltransferase (SAT) activity and higher steady-state GSH levels were in correlation with high expression levels of genes encoding SAT and glutathione reductase in $N$. goesingense. High expression of NgSAT in $A$. thaliana was reported to confer $\mathrm{Ni}, \mathrm{Co}$, and $\mathrm{Zn}$ tolerance, and to a small extent Cd tolerance [42]. According to Chen et al., (2015), AtMAN3, which encodes an endo-b-mannanase regulates Cd tolerance of Arabidopsis thaliana through the GSH-dependent PC synthesis pathway. In a line with this exposure to $\mathrm{Cd}$ trigger MAN3 expression followed by increase mannanase activity and a larger amount of mannose in cell walls [5, 9]. Furthermore, exposure to $\mathrm{Cd}$ triggers an ABC-type transporter AtABCC3 known as a transporter of PC-Cd complexes. This finding showed that overexpression of AtABCC3 increases $\mathrm{Cd}$ tolerance and vacuolar $\mathrm{Cd}$ content in protoplast [6]. Song et al. (2017) investigated Cd stressregulation pathway in transgenic Arabidopsis, which involves Ferrochelatase-1 (FC1, EC4.99.1.1) as the terminal enzyme encoded by AtFC1 gene. It was noted that activation of $\mathrm{AtFCl}$ by $\mathrm{Cd}$ exposure exceeded the primary root by PCs-dependent detoxifying pathway, and increased biomass and chlorophyll content [69].

As a metal chelator, GHS acts through its thiol groups, which have high metal-binding affinity [43]. GSH1 and GSH2 genes involved in GSH synthesis were identified in $A$. thaliana when exposed to $\mathrm{Cd}$ [43]. The expression of GSH1 and GSH2 contributed to $\mathrm{Cd}$ tolerance, while a decrease in GSH levels reduced $\mathrm{Cd}$ tolerance [43]. Furthermore, Arabidopsis AtFC1 regulate $\mathrm{Cd}$ stress response in hematin triggering GSH/PCs-synthesized gene expression, GSH1, GSH2, PCS1, and PCS2 [69]. It was also found that coexpression of PCS1 and GS in transgenic Arabidopsis increased $\mathrm{PC}$ production, $\mathrm{Cd}$, and As tolerance and accumulation [28].

Also, GSH is essential in Fe-mediated $\mathrm{Zn}$ tolerance in A. thaliana [43]. Xiang and Olive (1998) have treated Arabidopsis plants with $\mathrm{Cd}$ or $\mathrm{Cu}$. The plants responded by increased transcription of the genes for glutathione synthesis, g-glutamylcysteine synthetase, and glutathione synthetase, as well as glutathione reductase. The study showed that the response was specific for metals whose toxicity is thought to be mitigated through phytochelatins, and for toxic and nontoxic metals, which did not alter mRNA levels. It was also reported that neither oxidative stress (as a result of exposure to $\mathrm{H} 2 \mathrm{O} 2$ ) nor oxidized or reduced glutathione levels were responsible for activating transcription of these genes. Unlike $\mathrm{H} 2 \mathrm{O} 2$, oxidized or reduced glutathione, jasmonic acid treatment increased mRNA levels and the capacity for glutathione synthesis but did not increase the glutathione content in unstressed plants, which indicated that the glutathione concentration was controlled at multiple levels. Interestingly, jasmonic acid activated the same suite of genes for GA synthesis, which suggests that it might be involved in the signal transduction pathway for copper and cadmium [82]. Sidhu et al. (2018b) have pioneered the applicability of EDDS (chelant ethylenediamine disuccinic acid) to boost Ni-phytoextraction by Coronopus didymus. The results of the study indicated that EDDS treated soil increased antioxidant activities of superoxide dismutase, catalase, and glutathione peroxidase, raising of $\mathrm{H}_{2} \mathrm{O}_{2}$ content and MDA levels and production of superoxide anion. The increased antioxidant enzyme activity led to increased binding affinities to $\mathrm{Ni}$, as well as enhanced Ni translocation in plant tissues [66]. Also, it was found that Coronopus didymus has the potential to ameliorate $\mathrm{Pb}$-contaminated soils. The study showed greater $\mathrm{Pb}$ accumulation potential in roots compared with the shoots, with the bioconcentration factor less than 1, and the translocation factor greater than 1 [65].

The class of polyhydroxy steroids called Brassinosteroids (BRs) is found to have protective activity in the plants exposed to various stresses by the synthesis of antioxidant compounds in plants. One of the roles is in the syntheses of PC in plants exposed to lead [54] Although, at very low concentrations up to $120 \mathrm{ng} / \mathrm{kg}$, BRs can be found in the roots, the leaves, 
and the stem. Within the Brassicaceae family these steroidal plant hormones are present in Brassica napus L., Brassica campestris var. pekinensis L., Raphanus sativus L. and Arabidopsis thaliana L. but not in Brassica juncea plants [37].

To prevent biotic and abiotic stress caused by HMs, 70 BRs analogs have been identified in different cultivated plants, and among these, 24-epibrassinolide (24-eBL) [85]. Application of 24-eBL reduced uptake and accumulation of copper in B. junceae, and regulated developmental processes, such as biomass production [54]. Genetic analyses clearly showed the signal transduction pathway of BR, from the Brassinosteroid intensive 1 (BRI1) receptor kinase to transcriptional regulation by the Brassinazole resistant (BZR) family, involved in BR-mediated stress tolerance in Arabidopsis [79]. Based on the Genevestigator Arabidopsis thaliana Cd-regulated genes database, there is a similarity in gene expression in response to $\mathrm{Cd}$ and brassinosteroids (BR). Furthermore, Cd-induced activation of the BRsignalling pathway reflects in the expression of genes able to influence the $\mathrm{Cd}$ response [77]. Since the plasma membrane is the first line of defense, from $\mathrm{Cd}$ stress, activation of the plasma membrane protection enzymes H+-ATPase and NADPH oxidase by BR gives a new perspective. Therefore, Arabidopsis thaliana transmembrane receptor BR insensitive 1 (BRI1) and the co-receptor BRI1-associated receptor kinase 1 (BAK1) regulate BR signaling processes and have a key role in transcription and gene regulation related to $\mathrm{Cd}$ stress regulation [55]. Also, B. juncea treated with EBL and 28-homobrassinolide (HBL) showed lower Ni exposed stress, by BRs stimulated the activity of some antioxidant enzymes [76]. Furthemore, Huang et al. (2018) showed that Brassica rapa BRI1 proteins BrBRI1-1, BrBRI1-2, and BrBRI1-3 had sequence similarity to Arabidopsis thaliana BRI1 (AtBRI1) [35].

Application of EDTA, EDDS chelants to increase $\mathrm{Cd}, \mathrm{Cu}$, and $\mathrm{Zn}$ uptake and accumulation by Brassica napus $L$. showed increased $\mathrm{Cd}$ accumulation in stems and leaves, $\mathrm{Zn}$ concentration was higher in stems with leaves, while higher $\mathrm{Cu}$ concentration was found in roots [38]. Meyer et al. (2011) compared PCs between Cd-hyperaccumulators $A$. halleri and $N$. caerulescens, and non-hyperaccumulator $A$. thaliana, and found that PCS1 gene from $A$. halleri and $N$. caerulescens showed lower expression than its orthologue from $A$. thaliana [47].

Unlike PCs, MTs are gene-encoded polypeptides [8;14]. (Metallothioneins (MTs) are a class of small cysteine-rich proteins with high binding affinity to metals via metal-binding motifs that provide sulfhydryl for interacting with divalent metal ions [43]. Based on the type of cysteine residues, MTs in higher plants are classified into four types: MT1, MT2, MT3, and MT4 [56]. There are some general trends in the tissuespecific expression of MT genes, with type-1 MTs expressed predominantly in roots, type-2 MTs in leaves, type-3 MTs in fruits, and type-4 MTs in seeds
[56]. According to Guo et al. (2008a), most active MT genes confer $\mathrm{Cu}$ tolerance and accumulation, MT4 types confer $\mathrm{Zn}$ tolerance and accumulation, and MT1, 2, and 3 types enhance tolerance to $\mathrm{Cd}$, but often not $\mathrm{Cd}$ accumulation. Hence, some difference in the gene expression levels between hyperaccumulators and non-accumulators has been found. In nonaccumulator plants, such as $A$. thaliana, MT1a and MT1b are expressed at high levels in roots during exposure to $\mathrm{Cd}, \mathrm{Cu}$, and $\mathrm{Zn}$, while in hyperaccumulator $N$. caerulescens the levels of MT1 mRNA were found in leaves constitutively higher than in roots [59]. As a consequence, NcMT1 and NcMT2 are expressed at much higher levels in $N$. caerulescens compared to A. thaliana. However, MT2 is constitutively expressed in both A. halleri and N.caerulescens [59, 75]. According to Roosens et al. (2004), in $N$. caerulescens, NcMT3 confers much greater levels of tolerance to $\mathrm{Cu}$ than to $\mathrm{Cd}$ and increases the intracellular $\mathrm{Cd}$ concentrations. NcMT3 and AtMT3 expressed in the yeast mutant both showed similar Cd tolerance. However, better growth of yeast expressing NcMT3 than AtMT3 under Cd exposure, implies that NcMT3 can chelate more $\mathrm{Cu}$ than AtMT3 [58]. Furthermore, expression of B. juncea BjMT2 gene in A. thaliana, increased not only $\mathrm{Cu}$ but also Cd tolerance [90]. A member of type-1 MT genes, MT1, is found to be expressed in leaves of Brassica napus, Brassica rapa L. and Arabidopsis sp. exposed to Cd. Also, BrMT1 isolated from Brassica rapa has shown resistance to $\mathrm{Cd}$, in part, because its genome, has on average, 50\% DNA similarity in coding regions with the genome of hyperaccumulator $B$. juncea [40]. Arabidopsis has seven active MT genes belonging to four types (MT1a, MT1c; MT2a, MT2b; MT3; MT4a and MT4b) and one pseudogene (MT1b) [56]. MT gene expression is highly induced by $\mathrm{Cu}$ exposure, and a correlation between type 2 MT gene expression and $\mathrm{Cu}$ tolerance has been concluded from studies of Arabidopsis ecotypes [27]. Ren et al. (2012) investigated the functions of Arabidopsis AtMT4a and AtMT4b genes, in seed development, germination, and early seedling growth. This study showed that AtMT4a and AtMT4b are responsible for the accumulation of some important metal ions in late embryos [56]. As well, phytohormones abscisic acid (ABA) and gibberellic acid (GA) was found to be important in regulating the expression and function of AtMT4a and AtMT4b during seed development. In many Brassicaceae species, including metal hyperaccumulators A. halleri, non-hyperaccumulator relatives $A$. lyrata, A. thaliana, and metal hyperaccumulators N.goesingense and $N$. caerulescens, MT gene expression is strongly induced by $\mathrm{Cu}$ treatment and, to a lesser degree, by $\mathrm{Cd}$ and $\mathrm{Zn}$ [43]. Additionally, MT genes protect the plant from heavy metal toxicity by their MT genes expression, which presents the main difference between hyperaccumulator plants and non-hyperaccumulator plants. Significantly, this reflects their important role in phytoremediation [8]. 


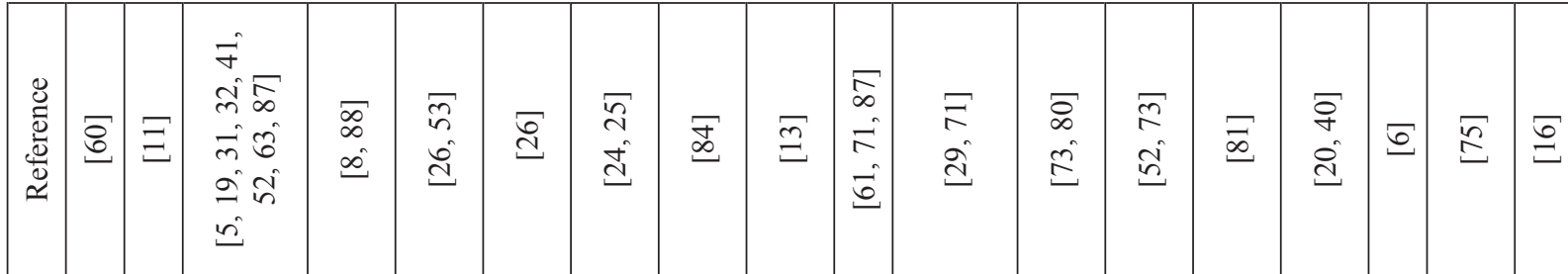

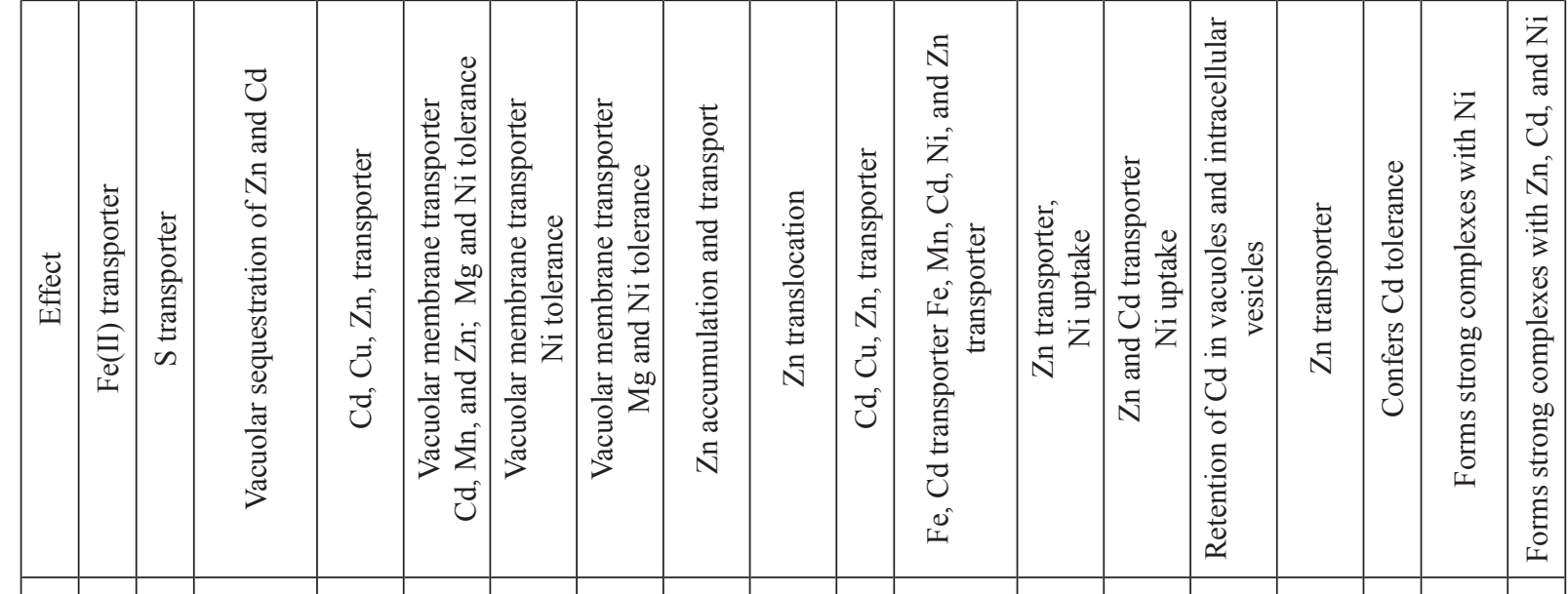

\begin{tabular}{|c|c|c|c|c|c|c|c|c|c|c|c|c|c|c|c|c|c|}
\hline 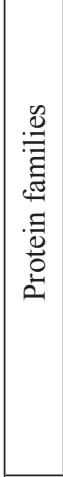 & 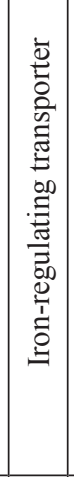 & 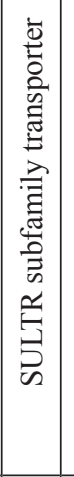 & 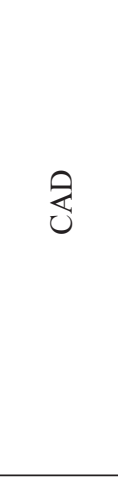 & 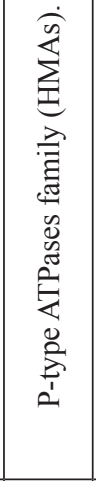 & 氛 & 氛 & 氛 & 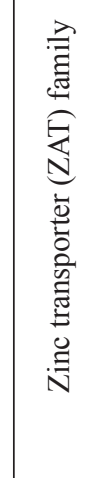 & 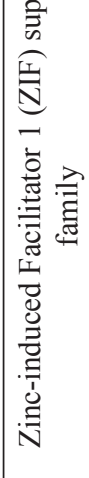 & 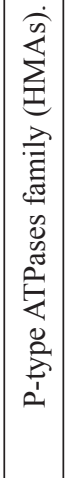 & 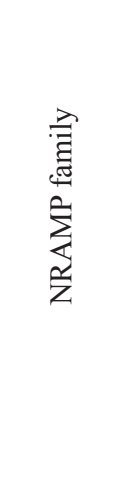 & 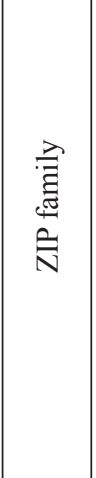 & 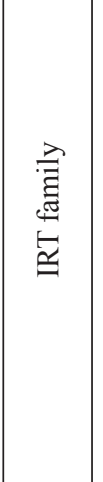 & 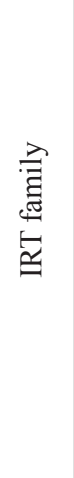 & 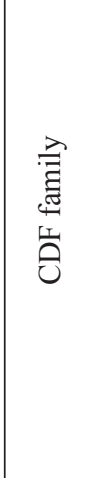 & 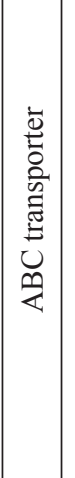 & 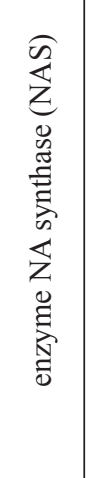 \\
\hline$\frac{\vec{E}}{\underline{a}}$ & 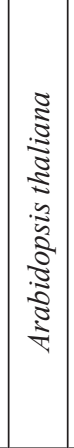 & 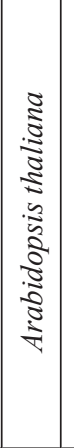 & 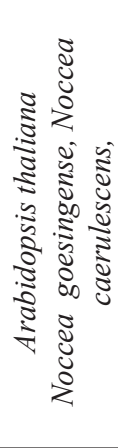 & 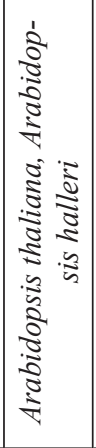 & 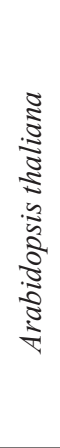 & 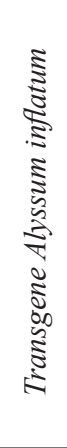 & 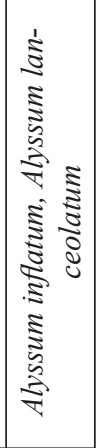 & 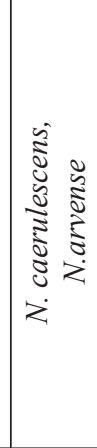 & 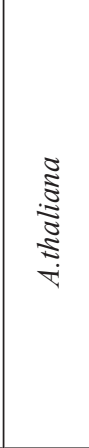 & 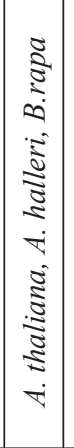 & 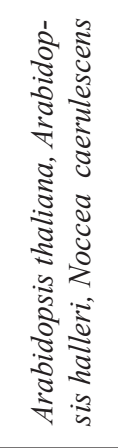 & 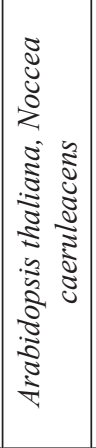 & 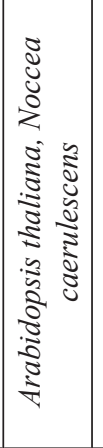 & 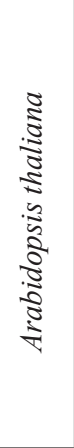 & 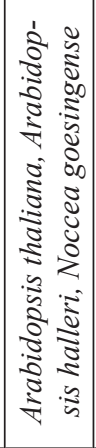 & 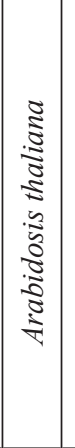 & 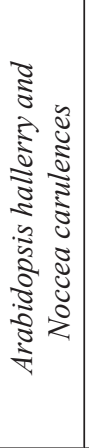 \\
\hline 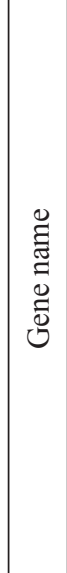 & $\overrightarrow{\underline{G}}$ & 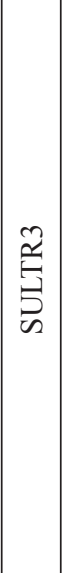 & 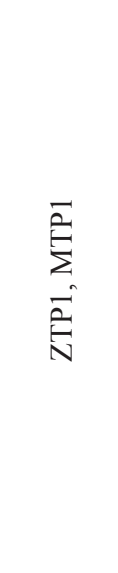 & $\sum_{\substack{\infty\\
}}^{+\infty}$ & 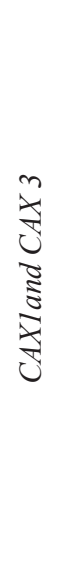 & 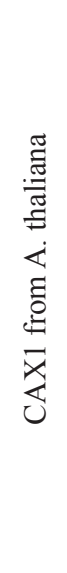 & $\vec{J}$ & 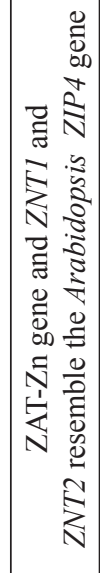 & 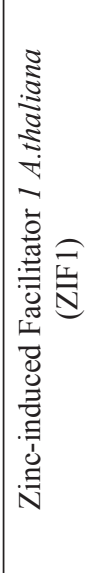 & 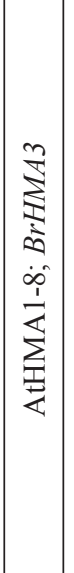 & 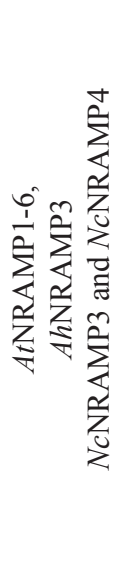 & 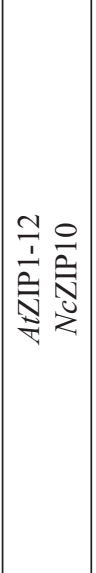 & 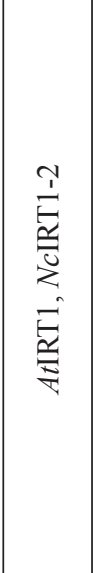 & 疍 & 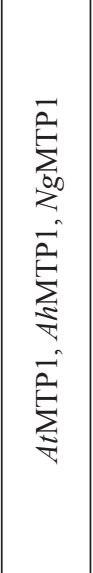 & 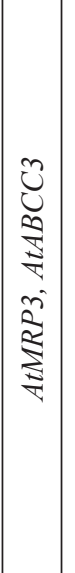 & 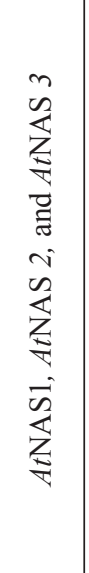 \\
\hline
\end{tabular}




\begin{tabular}{|c|c|c|c|c|c|c|c|c|c|c|c|}
\hline $\bar{\Omega}$ & 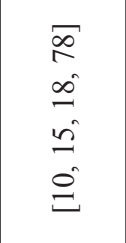 & $\stackrel{\sigma}{\Xi}$ & 胥 & $\begin{array}{l}\dot{\infty} \\
\tilde{g} \\
\tilde{g}\end{array}$ & $\vec{\infty}$ & $\stackrel{\widetilde{I}}{ \pm}$ & 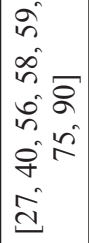 & $\sqrt[\widetilde{c}]{\tilde{c}}$ & $\begin{array}{l}\tilde{n} \\
n\end{array}$ & $\Xi$ & | \\
\hline 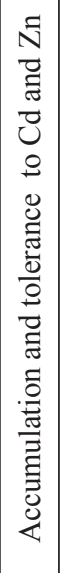 & 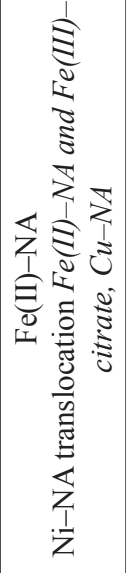 & 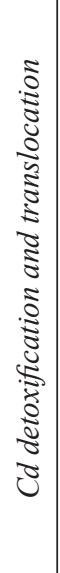 & 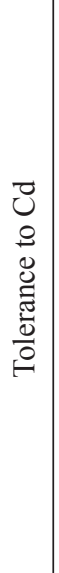 & 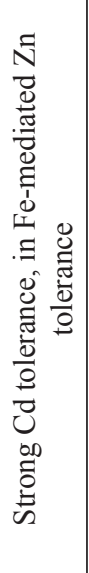 & 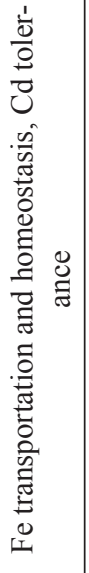 & 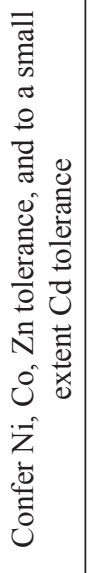 & 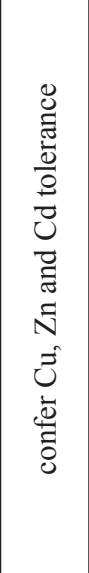 & $\begin{array}{l}0 \\
0 \\
\text { त्ञँ } \\
\frac{0}{0} \\
0 \\
0\end{array}$ & 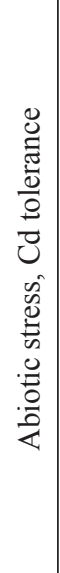 & 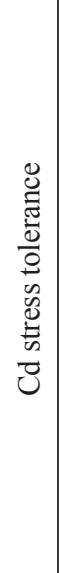 & $\begin{array}{l}0 \\
0 \\
\text { ज्ञ } \\
0 \\
0 \\
0 \\
0 \\
0 \\
0 \\
0 \\
0 \\
0 \\
0\end{array}$ \\
\hline 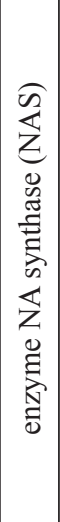 & 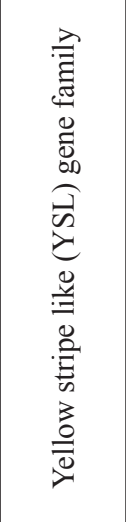 & 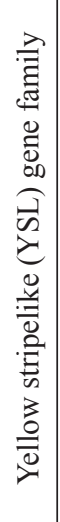 & 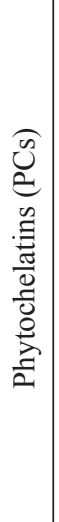 & 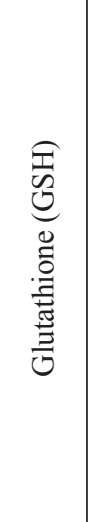 & 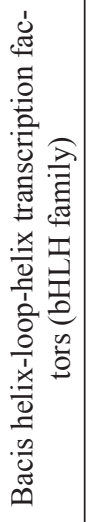 & 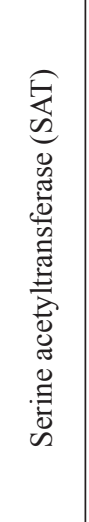 & 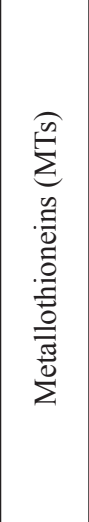 & 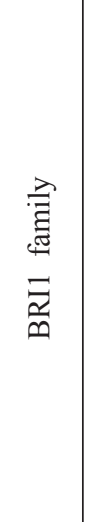 & 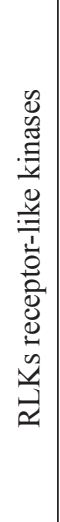 & 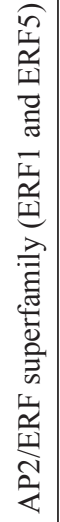 & 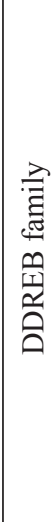 \\
\hline 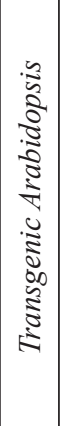 & 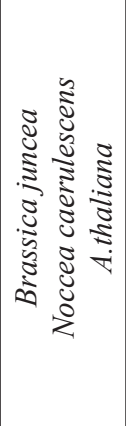 & 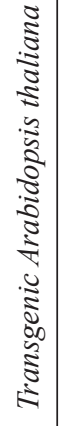 & 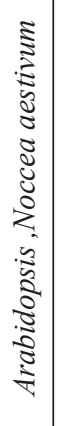 & 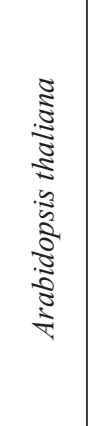 & 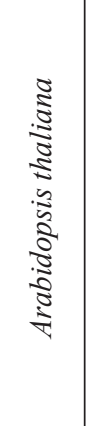 & 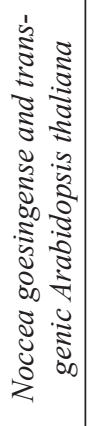 & 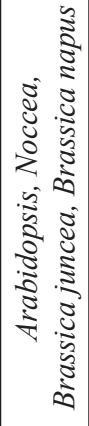 & 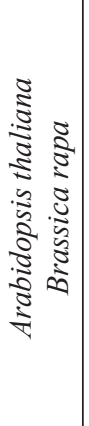 & 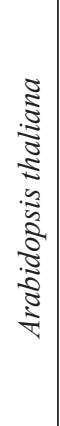 & 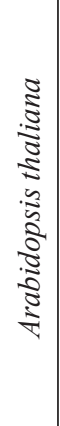 & 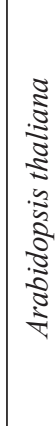 \\
\hline $\mid \begin{array}{l}n \\
z \\
z \\
n \\
n\end{array}$ & 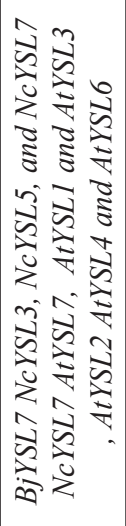 & 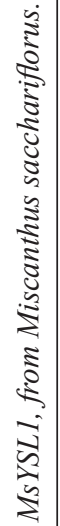 & 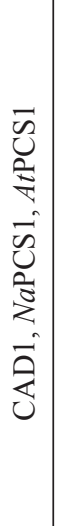 & 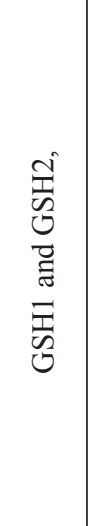 & 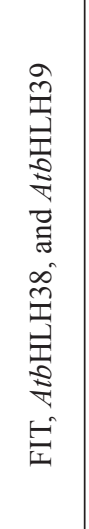 & $\begin{array}{l}\overline{7} \\
\text { s. } \\
z \\
z\end{array}$ & 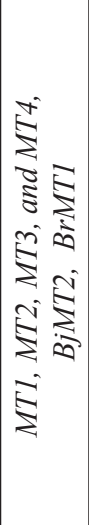 & 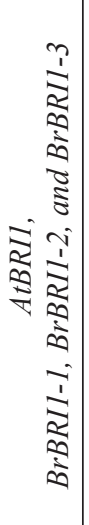 & $\begin{array}{l}\mathbb{Z} \\
\overline{7} \\
\bar{\nabla}\end{array}$ & 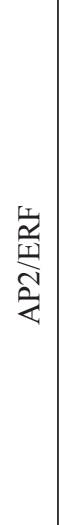 & 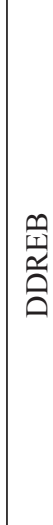 \\
\hline
\end{tabular}




\section{Conclusion}

The myriad of physicochemical methods for removal of the pollutants through effective is very expensive and not suitable where the city budgets are limited [48]. To tackle the problem of the metal-contaminated environment in the most economically end ecologically friendly way, construction of transgenic plants, based on the introduction of foreign genes, which are connected with uptake, transport, and accumulation of heavy metals, present a solution to clean up the urban environment. The review highlighted the remarkable results obtained from different studies regarding molecular aspects of proved accumulators of heavy metals in the Brassicaceae family. Most of the discovered hyperaccumulators belong to the genera Noccaea, Brassica, Alyssum and Arabidopsis [21]. The suitable candidates for the bio-removal of a wide range of heavy metals from the environment are shown in Table 1.

Table 1. Genes and proteins contributing to heavy metal tolerance or accumulation found in species of family Brassicaceae. Based on the results reviewed in this paper, the differences between species genetic blueprints in the same family provide more significant insights into the specific genes, their regulatory mechanisms, proteins, and informational pathway responses connected to phytoremediation. Variations on molecular levels within plants of one family are a way for populations to adapt to changing environments, landscapes, etc. The implication of this research is in the direct insertion of identified genes to enhance the metabolic capabilities and metal accumulating potential of Brassicaceae and other plant species.

\section{Conflict of Interest}

The authors declare no conflict of interest.

\section{Reference}

1. ABOU-SHANAB A.R., VAN BERKUM P., ANGLE S.J., DELOME A.T., CHANEY L.R. GHOZLAN A.H., GHANEM K., MOAWAD H. Characterization of Ni-resistant bacteria in the rhizosphere of the hyperaccumulator Alyssum murale by $16 \mathrm{~S}$ rRNA gene sequence analysis, World Journal of Microbiology \& Biotechnology, Biotechnol 26, 101, 2010.

2. AGNIHOTRI A., SETH C.S. Transgenic Brassicaceae: A Promising Approach for Phytoremediation of Heavy Metals. In Transgenic Plant Technology for Remediation of Toxic Metals and Metalloids, Academic Press, 239, 2019.

3. ALI B., GILL RA., YANG S., GILL MB., FAROOQ MA., LIU D., DAUD MK., ALI S., ZHOU W. Regulation of cadmium-induced proteomic and metabolic changes by 5-aminolevulinic acid in leaves of Brassica napus L. PLoS One. 10 (4), 1, 2015.

4. AMARI T., GHNAYA T., ABDELLY C. Nickel, cadmium and lead phytotoxicity and potential of halophytic plants in heavy metal extraction. South African Journal of Botany. 111, 99, 2017.

5. ANTOSIEWICZ D.M., BARANASZ A., SIEMIANOWSKI O. Phenotypic and molecular consequences of overexpression of metal-homeostasis genes. Frontiers in Plant Science. 5, 80, 2014.

6. BRUNETTI P., ZANELLA L., De PAOALIS A., LITTA D.D., CECCHETTI V., FALASCA G., BARBIERI M., ALTAMURA M.M., COASTANTINO P., CARDARELLI M. Cadmium-inducible expression of the ABCtype transporter AtABCC3 increases phytochelatinmediated cadmium tolerance in Arabidopsis. Journal of Experimental Botany, 66, 381, 2015.

7. BUNDU J.G., KILLE P., LIEBEKE M., SPURGEON D.J. (2014) Metallothioneins May Not Be Enough. The Role of Phytochelatins in Invertebrate Metal Detoxification. Environmental science \& technology $\mathbf{4 8}$ (2), 885, 2014.

8. CHAUNDHARY K., AGARWAL S., KHAN S., 2018. Role of phytochelatins (PCs), metallothioneins (MTs), and heavy metal ATPase (HMA) genes in heavy metal tolerance. In Mycoremediation and Environmental Sustainability. Springer, Cham., 39, 2018.

9. CHEN J., YANG L., GU J., BAI, X., REN, Y., FAN, T., HAN Y., JIANG L., XIAO F., LIU Y., CAO S. MAN 3 gene regulates cadmium tolerance through the glutathione-dependent pathway in Arabidopsis thaliana. New Phytologist, 205 (2), 570, 2015.

10. CHEN H., ZHANG C., GUO H., HU Y., HE Y., JIANG D. Overexpression of a Miscanthus sacchariflorus yellow stripe-like transporter MsYSL1 enhances resistance of Arabidopsis to cadmium by mediating metal ion reallocation. Plant Growth Regulation, 85 (1), 101, 2018.

11. CHEN Z., ZHAO P. X., MIA Z. Q., QI G. F., WANG Z., YUAN Y., AHMAD N., CAO M.J., HELL. R.,WIRTZ M., XIANG C. B. SULTR3s function in chloroplast sulfate uptake and affect ABA biosynthesis and the stress response. Plant physiology, 180 (1), 593, 2019a.

12. CHEN S., ZHANG M., FENG Y., SAHITO Z.A., TIAN S., YANG X. Nicotianamine Synthase Gene 1 from the hyperaccumulator Sedum alfredii Hance is associated with $\mathrm{Cd} / \mathrm{Zn}$ tolerance and accumulation in plants. Plant and Soil, 443 (1-2), 413, 2019b.

13. CLEMENS S., DEINLEIN U., AHMADI H., HORETRH S., URAGUCHI S. Nicotianamine is a major player in plant Zn homeostasis. Biometals, 26 (4), 623, 2013.

14. COBBETT C., GOLDSBROUGH P. Phytochelatins and metallothioneins, roles in heavy metal detoxification and homeostasis. Annual Review of Plant Biology, 53,159, 2002.

15. CONTE SS., CHU HH., CHAN-RODRIGEZ D., PUNSHON T., VASQUES KA., SALT DE., WALKER E.L. Arabidopsis thaliana yellow stripel-like4 and yellow stripel-like6 localize to internal cellular membranes and are involved in metal ion homeostasis. Front Plant Sci., 4, 283, 2013.

16. CORNU J.Y., DEINLEIN U., HORETH S., BRAUN M., SCHMIDT H., WEBER M., PERSSON D.P., HUSTED S., SCHJOERRING J.K., CLEMENS S. Contrasting effects of nicotianamine synthase knockdown on zinc and nickel tolerance and accumulation in the zinc/ cadmium hyperaccumulator Arabidopsis halleri. New Phytologist, 206 (2), 738, 2015.

17. CURIE C., CASSIN G., COUCH D., DIVOL F., HIGUCHI K., LE JEAN M. MISSON J., SCHIKORA A., CYERNIC P., MARI S. Metal movement within the plant: 
contribution of nicotianamine and yellow stripe 1-like transporters. Annals of Botany, 103, 1, 2009.

18. DIVOL F., COUCH D., CONEJERO G., ROSCHZTTARDTZ H., MARI S., CURIE C. The Arabidopsis yellow stripe like4 and 6 transporters control iron release from the chloroplast. Plant Cell 25, 1040, 2013

19. DROZDOVA I., ALEKSEEVA-POOPOVA N., DOROFEYEV V., BECH, J., BELYAEVA A., ROCA N. A comparative study of the accumulation of trace elements in Brassicaceae plant species with phytoremediation potential. Applied Geochemistry, 108, 104, 2019.

20. DRAGER D.B, DESBROSSES-FONROUGE A.G., KRACH C., CHARDONNENS A.N., MEYER R.C, SAMITOU-LAPRADE P., KRAMER U. Two genes encoding Arabidopsis halleri MTP1 metal transport proteins co-segregate with zinc tolerance and account for high MTP1 transcript levels, The Plant Journal, 39, 425, 2004.

21. FREEMAN J.L, PERSANS W.M., NIEMAN K, ALBRECHT C., PEER W., PICKERING J.I., SALTA E.D. Increased Glutathione Biosynthesis Plays a Role in Nickel Tolerance in Thlaspi Nickel Hyperaccumulators. The Plant Cell, 16, $2176,2004$.

22. GALL E.J., RAJAKARUNA N. The physiology, functional genomics, and applied ecology of heavy metaltolerant Brassicaceae In: Brassicaceae: Characterization, Functional Genomics and Health Benefits (Ed. Minglin Lang), Nova Science Publishers, Inc., NY, USA, 121, 2013.

23. GAUTAM P.K., GAUTAM R.K., BANERJEE S., CHATTOPADHYAYA M.C., PANDEY J.D. Heavy metals in the environment: fate, transport, toxicity and remediation technologies. Nova Science Publishers, 60, 101, 2016

24. GHASEMI R., CHAVOSHI Z.Z., BOYD R.S., RAJAKARUNA N. A preliminary study of the role of nickel in enhancing flowering of the nickel hyperaccumulating plant Alyssum inflatum Nya'rady. (Brassicaceae). South African journal of botany, 92, 47, 2015a.

25. GHASEMI R., CHAVOSHI Z.Z., GHADERIAN S.M. Stenocalcic properties in the serpentine-endemic plant Alyssum inflatum Nya'ra' dy.Australian Journal of Botany, 63, 31, $2015 b$.

26. GHASEMI R., SHARE H., SHARIFI R., BOYD R.S., RAJAKARUNA N. Inducing $\mathrm{Ni}$ sensitivity in the $\mathrm{Ni}$ hyperaccumulator plant Alyssum inflatum Nyárády (Brassicaceae) by transforming with CAX1, a vacuolar membrane calcium transporter. Ecological research, 33 (4), 737, 2018.

27. GUO W.J., MEETAM M., GOLSBROUGH P.B. Examining the specific contributions of individual Arabidopsis metallothioneins to copper distribution and metal tolerance. Plant Physiology, 146 (4), 1697, 2008a.

28. GUO J.B., DAI X., XU W., MA M. Overexpressing GSH1 and AsPCS1 simultaneously increases the tolerance and accumulation of cadmium and arsenic in Arabidopsis thaliana. Chemosphere, 72, 1020, 2008b.

29. HALL L.J. Cellular mechanisms for heavy metal detoxification and tolerance. Journal of experimental botany $\mathbf{5 3}, 366, \mathbf{2 0 0 2}$

30. HANIKENNE M., NUET C. Metal hyperaccumulation and hypertolerance: a model for plant evolutionary genomics. Current Opinion in Plant Biology 14, 252, 2011.

31. HASSAN Z., AARTS M.G.M. Opportunities and feasibilities for biotechnolog- ical improvement of $\mathrm{Zn}, \mathrm{Cd}$ or Ni tolerance and accumulation in plants. Environ. Exp. Bot., 72 53, 2011.

32. HANEY J.C., GRASS A.G., FRANKE A.S., RENSING C. New developments in the understanding of the cation diffusion facilitator family. Journal of Industrial Microbiology \& Biotechnology 32, 215, 2005.

33. HAYDON M.J., KAWACHI M., WIRTZ M., HILLMER S., HELL R., KRAMER U. Vacuolar nicotianamine has critical and distinct roles under iron deficiency and for zinc sequestration in Arabidopsis. Plant Cell, 24, 724, 2012.

34. HIGUCHI K., SUZUKI K., NAKANISHI H., YAMAGUCHI H., NOSHIZAWA N.K., MORI S. Cloning of nicotianamine synthase genes, novel genes involved in the biosynthesis of phytosiderophores. Plant Physiology, 119 (2), 471, 1999.

35. HUANG S., WANG H., GAN S, MAHMOUD ABDALLA MAHMOUD HUSSEIN M.A.M., WANG Q., WANG X., ZHANG Y., WANG X. Molecular identification and functional analysis of BrbRI1 as brassinosteroid receptor gene in Brassica rapa Pakistan Journal of Botany 50 (1), 85, 2018.

36. JIN F., WANG C., LIN H.J., SHEN Y.O., ZHANG Z.M., ZHAO M.J, PAN G.T. Heavy metal -transport proteins in plants: a review. Ying Yong Sheng Tai Xue Bao/The Journal of applied ecology, 21, 1875, 2010.

37. KANWAR M. K., BHARDWAJ R., CHOWDHARY S. P., ARORA P., SHARMA P., KUMAR S. Isolation and characterization of 24-Epibrassinolide from Brassica juncea L. and its effects on growth, $\mathrm{Ni}$ ion uptake, antioxidant defense of Brassica plants and in vitro cytotoxicity. Acta physiologiae plantarum, 35 (4), 1351, 2013.

38. KASIULIENE A., PAULAUSKAS V., KUMPIENE J. Chelant-assisted accumulation of $\mathrm{Cd}, \mathrm{Cu}$, and $\mathrm{Zn}$ in rapeseed (Brassica napus L.) biomass as a renewable energy feedstock. Polish Journal of Environmental Studies, 25 (5), 1985, 2016.

39. KHALILOVA H., MAMMADOV V. Assessing the Anthropogenic Impact on Heavy Metal Pollution of Soils and Sediments in Urban Areas of Azerbaijan's Oil Industrial Region. Polish Journal of Environmental Studies, 25, 1, 2016.

40. KIM S.H., LEE H.S., SONG W.Y., CHOI K.S., HUR Y. Chloroplast-targeted BrMT1 (Brassica rapa Type-1 metallothionein) enhances resistance to cadmium and ROS in transgenic Arabidopsis plants. Journal of Plant Biology, 50, 1, 2007.

41. KRÄMER U. MTP1 mops up excess zinc in Arabidopsis cells. Trends in Plant Science, 10, 313, 2005.

42. KRÄMER U. Metal Hyperaccumulation in Plants. The Annual Review of Plant Biology, 61, 517, 2010.

43. LIN Y.F., AARTS M.G. The molecular mechanism of zinc and cadmium stress response in plants. Cellular and molecular life sciences, 69 (19), 3187, 2012.

44. LIN Y.F., SEVERING E., LINTEL H. B., SCHIJEN E., AARTS M.G.M. A comprehensive set of transcript sequences of the heavy metal hyperaccumulator Noccaea caerulescens. Frontiers in Plant Science, 5, 261, 2014.

45. LIN Y.F., HASSAN Z., TALUKDAR S., SCHAT H., AARTS M.G.M. Expression of the ZNT1 zinc transporter from the metal hyperaccumulator Noccaea caerulescens confers enhanced zinc and cadmium tolerance and accumulation to Arabidopsis thaliana. PloS one, 11 (3), 1, 2016.

46. MAESTRI E., MARMIROLI M., VISIOLI G., MARMIROLI N. Metal tolerance and hyperaccumulation: 
Costs and trade-offs between traits and environment. Environmental and Experimental Botany 68, 1, 2010.

47. MEYER C.L., PEISKER D., COURBOT M., CRACIUN A.R., CAZALE A.C., DESGAIN D., SCHAT H., CLEMENS S., VERBRUGGEN N. Isolation and characterization of Arabidopsis halleri and Thlaspi caerulescens phytochelatin synthases. Planta 234 (1), 83, 2011.

48. NIKOLIĆ M., STEVOVIĆ S. Family Asteraceae as a sustainable planning tool in phytoremediation and its relevance in urban areas. Urban Forestry \& Urban Greening 14, 782, 2015.

49. OLANIRAN A.O., BALGOBIND A., PILLAY B. Bioavailability of heavy metals in soil: impact on microbial biodegradation of organic compounds and possible improvement strategies. International journal of molecular sciences, 14 (5), 10197, 2013.

50. PAL R., RAI J.P.N. Phytochelatins: peptides involved in heavy metal detoxification. Applied Biochemistry and Biotechnology, 160, 945, 2010.

51. PANTOLA R.C., ALAM A. Potential of brassicaceae burnett (Mustard family; Angiosperms) in phytoremediation of heavy metals. International Journal of Scientific Research in Environmental Sciences, 2 (4), 120, 2014.

52. PENCE N.S., LARSEN P.B., EBBS S.D., LETHAM D.L.D., LASAT M.M., GARVIN D.F., EIDE ., KOCHIAN L.V. The molecular physiology of heavy metal transport in the $\mathrm{Zn} / \mathrm{Cd}$ hyperaccumulator Thlaspi caerulescens. Proceedings of the National Academy of Sciences of the United States of America 97, 4956, 2000.

53. PUNSHON T., HIRSCHI K., YANG J., LANZIROTTI A., LAI B., GUERINOT M.L. The role of CAX1 and CAX3 in elemental distribution and abundance in Arabidopsis seed. Plant Physiology, 158 (1), 352, 2012.

54. RAJEWSKA I., TALAREK M., BAJGUZ A. Brassinosteroids and response of plants to heavy metals action. Frontiers in plant science 7, 629, 2016.

55. RAMENENI J.J., LEE Y., DHANDAPANI V., YU X., CHOI S.R., OH M.H.,LIM Y.P. Genomic and posttranslational modification analysis of leucine-rich-repeat receptor-like kinases in Brassica rapa. PLoS One, 10 (11), $1,2015$.

56. REN Y., LIU Y., CHEN H., LI G., ZHANG X., ZHAO J.I.E. Type 4 metallothionein genes are involved in regulating $\mathrm{Zn}$ ion accumulation in late embryo and in controlling early seedling growth in Arabidopsis. Plant, cell \& environment, 35 (4), 770, 2012

57. RODRIGUEZ-BOCANEGRA J., ROCA N., FEBRERO A., BORT J. Assessment of heavy metal tolerance in two plant species growing in experimental disturbed polluted urban soil. Journal of Soils and Sediments, 18 (6), 2305, 2018.

58. ROOSENS N.H., BERNARD C., LEPLAE R., VERBRUGGEN N. Evidence for copper homeostasis function of metallothionein (MT3) in the hyperaccumulator Thlaspi caerulescens. FEBS Letters, 577, 9, 2004.

59. ROOSENS N.H., LEPLAE R., BERNARD C., VERBRUGGEN N. Variations in plant metallothioneins: the heavy metal hyperaccumulator Thlaspi caerulescens as a study case. Planta 222 (4), 716, 2005.

60. SALOME A.P. Reverse Genetics of IRT1, or How to Catch an Iron Transporter and Pin It Down. Plant Cell, 31 (6), 1200, 2019.

61. SANO T., HANDA K., SATO M.H, HASEZAWA S., YOSHIHARA T., NAGATA T. Metal Ion Homeostasis
Mediated by NRAMP Transporters in Plant CellsFocused on Increased Resistance to Iron and Cadmium Ion. Crosstalk and integration of membrane trafficking pathways 213, 2012.

62. SCHELLER H.V., HUANG B., HATCH E., GOLDSBROOUGH P.B. Phytochelatin synthesis and glutathione levels in response to heavy metals in tomato cells. Plant Physiology 85 (4), 1031,1987.

63. SHAHZAD Z., GOSTI F., FREROT H., LACOMBE E., ROOSENS N.H, SAUMITOU L.P., BERTHOMEU P. The five AhMTP1 zinc transporters undergo different evolutionary fates towards adaptive evolution to zinc tolerance in Arabidopsis halleri. PLoS Genet 6, 1, 2010.

64. SCHULER M., RELLAN-ALVAREZ R., FINKSTRAUBE C., ABADIA J., BAUER P. Nicotianamine functions in the phloem-based transport of iron to sink organs, in pollen development and pollen tube growth in Arabidopsis. Plant Cell, 24, 2380, 2012.

65. SIDHU G.P.S., BALI A.S., SINGH H.P., BATISH D.R., KHLI R.K. Phytoremediation of lead by a wild, non-edible $\mathrm{Pb}$ accumulator Coronopus didymus (L.) Brassicaceae. International journal of phytoremediation, 20 (5), 483, 2018 a.

66. SIDHU G.P.S., BALI A.S., SINGH H.P., BATISH D.R., KHLI R.K. Ethylenediamine disuccinic acid enhanced phytoextraction of nickel from contaminated soils using Coronopus didymus (L.) Sm. Chemosphere, 205, 234, 2018b.

67. SING S., PARIHAR P., SINGH R., SINGH V.P., PRASAD S. M. Heavy metal tolerance in plants: role of transcriptomics, proteomics, metabolomics, and ionomics. Frontiers in plant science, 6, 1143, 2016.

68. SOLANKI R., DHANKHA R. Biochemical changes and adaptive strategies ofplants under heavy metal stress. Biologia, 66, 195, 2011.

69. SONG J., FENG S.J., CHEN J., ZHAO W.T.,YANG Z.M. A cadmium stress-responsive gene AtFCl confers plant tolerance to cadmium toxicity. BMC plant biology, 17 (1), $187,2017$.

70. SUZUKI K., HIGUCHI K., NAKANISHI H., NISHIZAWA N.K, MORI S. Cloning of nicotianamine synthase genes from Arabidopsis thaliana. Soil science and plant nutrition, 45 (4), 993, 1999.

71. TAKAHASHI R., BASHIR K., ISHIMARU I., NISHIZAVA K. N., NAKANISHI H. The role of heavymetal ATPases, HMAs, in zinc and cadmium transport in rice. Plant Signaling \& Behavior 7 (12), 1605, 2012.

72. TANG R.J., ZHAO F.G., GARCIA V.J., KLEIST T.J., YANG L., ZHANG H.X., LUAN S. Tonoplast CBLCIPK calcium signaling network regulates magnesium homeostasis in Arabidopsis. Proceedings of the National Academy of Sciences, 112 (10), 3134, 2015.

73. TENG Y.T., STRECKEMAN T., ECHEVARRIA G., MOREL J.L., QJU R.L. Effects of the interactions between nickel and other trace metals on their accumulation in the hyperaccumulator Noccaea caerulescens. Environmental and experimental botany, 158, 73, 2019.

74. THAMILARASAN S.K., PARK J.I., JUNG H.J., NOU I.S. Genome-wide analysis of the distribution of AP2/ ERF transcription factors reveals duplication and CBFs genes elucidate their potential function in Brassica oleracea. BMC genomics, 15 (1), 422, 2014.

75. VAN DE MORTEL J.E., VILLANUEVA L.A., SCHAT H., KWEKKBOO M. J., COUGHLAN S., MOERLAND P.D., VER LOREN VAN THEMAAT E., KOORNNEEF M., AARTS M.G.M. Large expression differences in genes 
for iron and zinc homeostasis, stress response, and lignin biosynthesis distinguish roots of Arabidopsis thaliana and the related metal hyperaccumulator Thlaspi caerulescens. Plant Physiology, 142, 1127, 2009.

76. VAZQUEZ M.N., GUERRERO Y.R., GONZALES L.M., DE LA NOVAL W.T. Brassinosteroids and plant responses to heavy metal stress. An overview. Open Journal of Metal, 3, 34, 2013.

77. VILLIERS F., JOURDAIN A., BASTIEN O., LEONHARDT N., FUJIOKA S., TICHTINCKY G., PARCY F., BOURGUIGNON J., HUGOUVIEUX V. Evidence for functional interaction between brassinosteroids and cadmium response in Arabidopsis thaliana. Journal of experimental botany, 63 (3), 1185, 2012.

78. WANG J.W., LI, Y., ZHANG, Y.X. CHAI T.Y. Molecular cloning and characterization of a Brassica juncea yellow stripe-like gene, BjYSL7, whose overexpression increases heavy metal tolerance of tobacco. Plant cell reports, 32 (5), 651, 2013.

79. WANG W., BAI M. Y., WANG Z.Y. The brassinosteroid signaling network - a paradigm of signal integration. Current opinion in plant biology, 21, 147, 2014.

80. WEBER M., HARADA E., VESS C., ROEPENACK LAHAYE E.V., CLEMENS S. Comparative microarray analysis of Arabidopsis thaliana and Arabidopsis halleri roots identifies nicotianamine synthase, a ZIP transporter and other genes as potential metal hyperaccumulation factors. The Plant Journal, 37 (2), 269, 2004.

81. WU H., CHEN C., DU J., LIU H., CUI Y., ZHAN Y., YIQING H., WANG Y., CHU C., FENG Z., LI J., LING H.O. Co-overexpression FIT with AtbHLH38 or AtbHLH39 in Arabidopsis -enhanced cadmium tolerance via increased cadmium sequestration in roots and improved iron homeostasis of shoots. Plant Physiology, 158, 790, 2012.

82. XIANG C., OLIVER D.J. Glutathione metabolic genes coordinately respond to heavy metals and jasmonic acid in Arabidopsis. The Plant Cell 10 (9), 1539, 1998.

83. XIAO-E Y., XIAO-F J., YING F., EJAZUL I. Molecular Mechanisms and Genetic Basis of Heavy Metal Tolerance/
Hyperaccumulation in Plants. Journal of Integrative Plant Biology/Formerly Acta Botanica Sinica 47 (9) 1025, 2005.

84. YANG X., FENGA Y., HEA Z., STOOFFELLAB J.P. Molecular mechanisms of heavy metal hyperaccumulation and phytoremediation. Journal of Trace Elements in Medicine and Biology 18, 339, 2005.

85. YIGIT T., SAHINER A., BAYDAR N.G., BABLIK Z., DEMITCI T. Determination of the best 24-eBL application for the accumulation of antioxidant compounds in 'Alphonse Lavallée' grape cultivar by using fuzzy logic modelling. "X International Symposium on Modelling in Fruit Research and Orchard Management. Acta Horticulturae. 1160, 381, 2015.

86. YUSUF M., FARIDUDDIN Q., HAYAT S., AHMAD A. Nickel: an overview of uptake, essentiality and toxicity in plants. Bulletin of Environmental Contamination and Toxicology, 86, 1, 2011,

87. ZANG L., WU J., TANG Z., HUANG X-Y., WANG X., SALT E D., YHAO F-J. Variation in the BrHMA3 coding region controls natural variation in cadmium accumulation in Brassica rapa vegetables. Journal of Experimental Botany, 70 (20), 5865, 2019.

88. ZHANG J., MARTINOJA E., LEE Y. Vacuolar transporters for cadmium and arsenic in plants and their applications in phytoremediation and crop development. Plant and Cell Physiology, 59 (7), 1317, 2018.

89. ZEMANOVA V., PAVLIK M., PAVLIKOVA D., TLUSTOS P. The changes of contents of selected free amino acids associated with cadmium stress in Noccaea caerulescens and Arabidopsis halleri. Plant, Soil and Environment, 59 (9), 417, 2013

90. ZHIGANG A., CUIJIE L., YUANGANG Z., YEJIE D., WACHTER A., GROMES R., RAUSCH T. Expression of BjMT2, a metallothionein 2 from Brassica juncea, increases copper and cadmium tolerance in Escherichia coli and Arabidopsis thaliana, but inhibits root elongation in Arabidopsis thaliana seedlings. Journal of experimental botany, 57 (14), 3575, 2006. 